\title{
Consumer Preferences and Brand Equity Measurement of Spanish National Daily Newspapers: A Conjoint Analysis Approach
}

\author{
Jesús Varela Mallou, Antonio Rial Boubeta, and Teresa Braña Tobío \\ University of Santiago de Compostela
}

Brand is a product attribute that, for many types of goods or services, makes a major contribution to consumer preferences. Conjoint analysis is a useful technique for the assessment of brand values for a given consumer or group of consumers, In this paper, an application of conjont analysis to the estimation of brand values in the Spanish daily newspaper market is reported. Four newspaper attributes were considered: brand (i.e., newspaper name), price $(0.60,1.05$, or 1.50 euros), Sunday supplement (yes/no), and daty pullow (yes/ro). A total of 510 regular readers of the national press, stratified by age and sex, were asked to rank 16 profiles representing an orthogonal fraction of the possible attribute-level combinations. Brand was by far the most important attribute, whereas price had negligible effect. More generally, the results confirm the utility of conjoint analysis for assessing brand equity in the newspaper market and for estimating the relative importance of the various attributes to different subgroups of consumers.

Key words: consumer behavior, brand equity, conjoint analysis

La marca es el atributo de un producto o servicio que puede ejercer gran influencia en las preferencias de los consumidores. El análisis conjunto es una técnica muy útil para conocer el valor que una marca tiene para un grupo de consumidores. En este trabajo se presenta una aplicación del análisis conjunto en la estimación del valor de la marca en el mercado de la prensa nacional española. Se han considerado cuatro atributos de un periódico: la marca (el nombre del periódico), el precio $(0.60,1.05$ ó 1.50 euros), ef Suplemento Dominical (con o sin suplemento), y el Cuadernillo Diario (con o sin cuadernillo). La muestra, compuesta por un total de 510 lectores habituales de prensa nacional, fue estratificada por edad y sexo. Los sujetos tuvieron que ordenar 16 estimulos que representaban una fracción ortogonal de todas las combinaciones de atributos $y$ niveles posibles. Los resultados muestran que la marca es el atributo más importante, mientras que el precio tiene un efecto mínimo. Además, éstos confirman la utilidad que tiene el análisis conjunto para conocer el valor de la marca en el caso de un periódico, así como para estimar la importanciá relativa de distintos atributos en diversos grupos de consumidores.

Palabras clave: comportamiento del consumidor, valor de la marca, análisis conjunto

This work was carried out with financial support from the European Union (FEDER IFD97-0158) and the collaboration of Sondaxe (Grupo Voz).

Address correspondence to: Prof. Dr. Jesús Varela Mahlou, Dpto. Metodología de las Ciencias del Comportamiento. Facultad de Psicología. Universidad de Santiago de Compostela. 15706 Santiago, A Coruña (Spain). E-mail: mtsuso@usc.es Http: www.usc.es/psicom 
In both the academic and business worlds, it is nowadays widely recognized that a prestigious brand image is critical to the success of most types of product or service. Brand equity -defined by Farquhar (1989) as "the added value supplied by the brand to the product"is often a company's key isset, exceeding the value of its financial assets. How else can we explain the fact that Philip Morris bought the Kraft brand for more than 6 times its estimated financial value, or the fact that the masthead of a national newspaper may cost up to $\$ 50$ million? Strong brand equity allows the company to negotiate from a position of strength with distributors, to take up the lead position in a given product category, to move with relative ease into other product categories, or to opt for cobranding in association with other prestigious brands. In other words, "the product is no longer king," and the success of companies ends up depending on marketing. Such success is, of course, not casily achieved. Numerous recent studies have indicated that brand equity develops gradually over time, and requires careful management if it is to become a valuable asset (Aaker, 1991, 1996; Kapferer, 1992; Kapferer \& Thoenig, 1991; Low \& Fulterton, 1994; Park \& Srinivasan, 1994; Shocker, Srivastava \& Ruekert, 1994).

In this context, accurate and objective assessment of brand value to consumers (and thus, the value of the brand to the company, i.e., brand equity) becomes a key goal for managers. One method for the assessment of brand value is conjoint analysis. This method is based on Lancaster's (1966) approach to consumer theory, within which the consumer is considered an active decision-maker. Specifically, the consumer is seen as a producer of satisfactions, and goods (products or services) are considered attribute sets. According to this approach, any product or service can be broken down into a basic functional utility (the basic service) and a set of secondary utilities of various types (aesthetic, social, cultural, safety, guarantee, prestige) that supplement the basic service (Loudon \& Della Bitta, 1988: Wilkie \& Pessemier, 1973). The sum of the partial utilities (partworth) adds up to the total utility of the product, as perceived by a given consumer or group of consumers. From the theoretical frameworks of Rosenberg (1956) and Fishbein (1967), the total utility of a product is a key determinant of the probability of its purchasc. Consideration of the individual partial utilities will thus aid understanding the relative importance of the individual attributes. For example, if one of the attributes under study is brand, we can estimate the extent to which this attribute governs purchase choice, thus moving into the field of decision models, and more specifically, that of compensatory decision-making, as extensively considered in the information integration theory proposed by Anderson (1974).

In this paper, we apply conjoint analysis to the estimation of brand values in the Spanish daily newspaper market.

\section{Conjoint Analysis}

The total utility $U$ of a given product can be considered to be the sum of the partial utilities of the various attributes of that product:

$\mathrm{U}=\sum_{\mathrm{i}=1}^{\mathrm{n}_{\mathrm{i}}} \mathrm{u}_{\mathrm{i}}\left(\mathrm{x}_{\mathrm{i}}\right)$

where $u_{i}$ is the partial utility function for attribute $i$, and $x_{i}$ is the perceived level of attribute $i$ in that product. Given observed values of $U$ (e.g., as inferred from preferences expressed by the consumer) and known values of $x_{j}$, conjoint analysis uses regression procedures to estimate $\mathrm{u}_{\mathrm{i}}$. Full details of these procedures can be seen in Green and Wind (1975), Varela and Braña (1996), or Huber (2000). In the present study, we used the program Conjoint (Norusis, 1994).

For each attribute, Conjoint additionally calculates relative importance $\left(w_{i}\right)$, which provides a measure of the importance attached to that attribute by the consumer or group of consumers under study:

$w_{i}=\frac{\operatorname{Max}\left(u_{i j}\right)-\operatorname{Min}\left(u_{i j}\right)}{\sum_{i=1}^{n_{i}}\left[\operatorname{Max}\left(u_{i j}\right)-\operatorname{Min}\left(u_{i j}\right)\right]} \times 100$,

where $u_{i j}$ is the value of $U_{i}$ at level $j$.

The principal aim of this study was to apply conjoint analysis to the assessment of consumer preferences as regards major Spanish national daily newspapers, with particular reference to brand (i.e., the name or masthead of the newspaper). To our knowledge, this is the first application of this approach to the assessment of brand value in this product category. Additionally, estimation of the partial utilities of each attribute considered can be expected to facilitate product design, whereas evaluation of partial utilities in different consumer groupings (sex, age, ctc.) may facilitate identification of market segmentation.

\section{Method}

\section{Participants}

The sample comprised 510 habitual readers of major national daily newspapers, all of whom were resident in Madrid and aged between 18 and 74 years. A random sampling procedure was used, with stratification by age group and sex. There were 323 men $(18-24$ years: $20 ; 25$ $34: 75 ; 35-44: 83 ; 45-54: 62 ; 55-64: 33$; over 65 years: 50 ) and 187 women ( $18-24$ years: $28 ; 25-34: 56 ; 35-44: 46$; $45-54: 24 ; 55-64: 20$; over 65 years: 13 ). The sample was also balanced according to participants preferred newspaper (newspaper A, B, C, or D), taking into account the data proportioned by the "Estudio General de Medios" (General Mcdia Study) corresponding to 1998. Sample size was 
sufficient to ensure a $95 \%$ confidence lovel and a maximum estimated error of $3 \%$.

\section{Stimulus}

Evidently, consumers' evaluations of newspapers are influenced by a large number of variables (attributes). However, our experience of the newspaper market in Spain suggested consideration of four variables only, namely, brand (i.e., name), price, Sunday supplement (yes/no), and daily central pullout (yes/no). To maintain confidentiality, we refer to the four newspapers (the four non-sports dajlies with largest readership in Madrid) as A, B, C, and D.

Given the large number of types that would result from consideration of all attribute $\times$ level combinations $(4 \times 3 \times$ $2 \times 2$ ), consumer preferences were directly determined only for an orthogonal fraction of the complete factorial design (Kirk, 1982), namely, the 16 types detailed in Table 1.

\section{Procedure}

Participants were randomly selected for intervicw in their homes by the random routes procedure, with progressive fulfillment of the age, sex, and preferred-newspaper stratification quotas (sce Participants). Once the participant had agreed to take part, he or she was presented with sixteen cards $(14 \times 8 \mathrm{~cm})$, each representing one of the 16 newspaper types shown in Table 1, and was asked to rank them physically according to preference. The ranking task typically lasted about 15 minutes.

\section{Data analysis}

The data were analyzed using the program Conjoint (Norusis, 1994). The observed preferences of each participant (1 for the most prelerred product, 16 for the least preferred product) were entered as Sequence data. The altribute price was modeled as Linear [Less] (i.e., the partial utility function was atssumed a priori to be decreasing linear). The remaining attributes wcre moteled as Discrcte (i.e., as cattegorical variables with no a priori assumptions athoul which would be preferred).

\section{Results}

The results of application of conjoint analysis to the data for the 510 participants are shown in Figure 1.

The model accounted for $82 \%$ of the total variance $(R=0.911, p<.0001)$, indicating that it provides a fairly accurate representation of participant preferences.

The most important determinant of preference was clearly brand (reJalive importance, $74.2 \%$ ): Sunday supplement $(18.4 \%)$ and daily pullout $(6.6 \%)$ were much less important, and price had negligible effect $(0.9 \%)$.

The a priori assumption that participants would prefer low prices to high prices was confirmed. Nevertheless, the mean increase in utility per 75-peseta drop in price was a negligible: 0.0213 uility units,

Note that this relationship allows us to estimate the amount of moncy a reader would be prepared to pay for a given improvement in al given attribute. For example, the difference

Table 1

Attribute levels for each of the 16 cards presented to participants

\begin{tabular}{|c|c|c|c|c|}
\hline & Brand & $\begin{array}{c}\text { Price } \\
\text { (in pesetas) }\end{array}$ & $\begin{array}{c}\text { Weckly } \\
\text { Supplement }\end{array}$ & $\begin{array}{l}\text { Daily } \\
\text { Pullout }\end{array}$ \\
\hline Stimulus 1 & C. & 250 & W & Wo \\
\hline Stimulus 2 & $B$ & 175 & W & W \\
\hline Stimulus 3 & C & 175 & Wo & W \\
\hline Stimulus 4 & A & 250 & W & Wo \\
\hline Stimulus 5 & A & 175 & Wo & Wo \\
\hline Stimulus 6 & $D$ & 250 & Wo & $w$ \\
\hline Stimulus 7 & $\mathrm{D}$ & 100 & Wo & Wo \\
\hline Stimulus 8 & A & 250 & Wo & $w$ \\
\hline Stimulus 9 & A & 100 & Wo & Wo \\
\hline Stimuizs 10 & $\mathrm{D}$ & 175 & $W$ & $W$ \\
\hline Stimulus 11 & $\mathrm{~A}$ & 100 & W & W \\
\hline Stimulus 12 & $\mathrm{C}$ & 100 & Wo & $W$ \\
\hline Stimulus 13 & $\mathrm{D}$ & 100 & $W$ & Wo \\
\hline Stimulus 14 & A & 100 & Wo & $W$ \\
\hline Stimulus 15 & B & 100 & W & Wo \\
\hline Stimulus 16 & $\mathrm{C}$ & 100 & $\mathrm{~W}$ & W \\
\hline
\end{tabular}

Note. $\mathrm{W}=$ with: $\mathrm{W}_{\mathrm{O}}=$ without. 


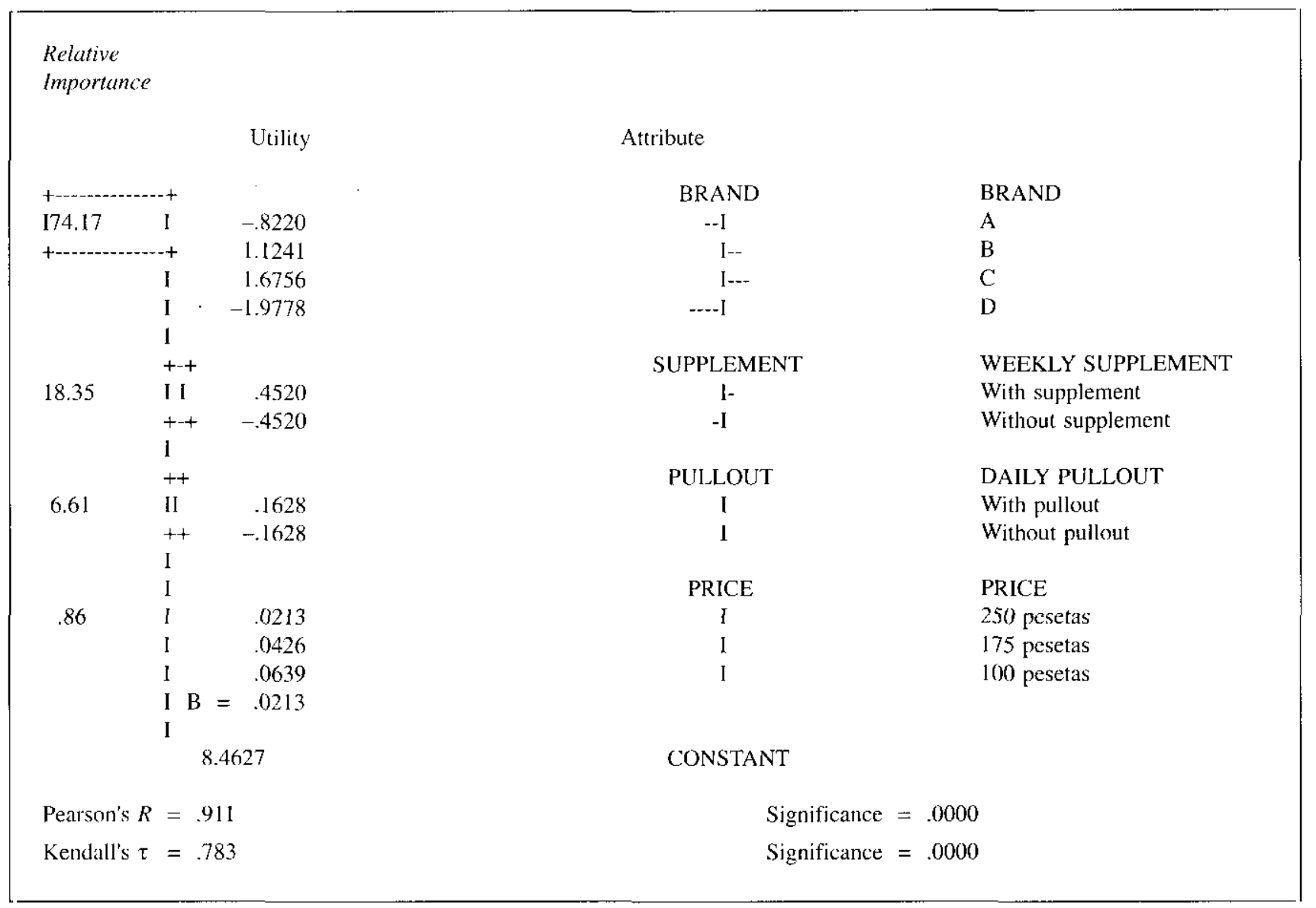

Figure 1. General results of the conjoint analysis.

in partial utility between brand C and brand D was 3.65 units (see Table 2). In price terms, this is equivalent to a difference of 172 pesetas (see Table 3). Within the price tange considered, this suggests that participants would buy brand $C$ even if it cost 250 pesetas and brand D cost 100 pesetas.

The total predicted utility of the "ideal" newspaper (brand C, with weekend supplement, daily central pullout, and price 100 pesetas $)$ was $10.82(1.67+0.45+0.16+0.06+8.46$, where 8.46 is the constant). The effect of increasing price from 100 to 250 pesetas would be minimal (overall utility

\section{Table 2}

Differences in the Partial Utility of Brand between the Four Newspapers

\begin{tabular}{lrrrrrr}
\hline & & \multicolumn{5}{c}{ Brand } \\
& & \multicolumn{1}{c}{$\mathrm{A}$} & $\mathrm{B}$ & $\mathrm{D}$ \\
\cline { 3 - 7 } $\mathrm{A}$ & -0.8220 & 0 & & & \\
$\mathrm{~B}$ & 1.1241 & 1.9461 & 0 & & \\
$\mathrm{C}$ & 1.6756 & 2.4976 & 0.5515 & 0 & \\
$\mathrm{D}$ & -1.9778 & -1.1558 & -3.1019 & -3.6534 & 0 \\
\hline
\end{tabular}

10.78). The total predicted utility of brand $\mathrm{C}$ with the worst possible attribute set (no weekend supplement, no daily pullout, price 250 pesetas) was 9.55 . This was still higher than the total predicted utilities for the least preferred brands (brands $A$ and D) with the best possible attribute set (scores 8.31 and 7.16 , respectively). This again illustrates the critical importance of brand.

It should be stressed that these quantifications of brand value are relative, in the sense that the value of a brand is quantified relative to that of the other competing brands. Thus,

Table 3

Differences in the Partial Utility of Brand between the Four Newspapers; Expressed in Terms of Price

\begin{tabular}{crrrrr}
\hline & & \multicolumn{5}{c}{ Brand } & \\
& & A & B & C & D \\
\cline { 3 - 6 } A & -0.8220 & 0 & & & \\
B & 1.1241 & 91.3 & 0 & & \\
C & 1.6756 & 117.2 & 25.8 & 0 & \\
D & -1.9778 & -54.2 & -145.6 & -171.52 & 0 \\
\hline
\end{tabular}


Table 4

Relative Importance ( $w_{i}$ ) of each Atribute for Participant Subgroups Defined by Sex, Age, and Newspaper Reading-Freguency

\begin{tabular}{|c|c|c|c|c|}
\hline & Brand & Price & Supplement & C. Section \\
\hline \multicolumn{5}{|l|}{ Sex } \\
\hline Tolat & 74.17 & 0.86 & 18.35 & 6.61 \\
\hline Men & 77.67 & 0.77 & 17.68 & 3.87 \\
\hline Women & 69.49 & 0.94 & 18.21 & 11.36 \\
\hline \multicolumn{5}{|l|}{ Age } \\
\hline $18-24$ Years & 43.82 & 3.59 & 26.29 & 26.29 \\
\hline $25-34$ Years & 73.69 & 2.88 & 14.71 & 8.72 \\
\hline $35-44$ Years & 77.47 & 3.60 & {$[4.73$} & 4.20 \\
\hline $45-54$ Year's & 75.43 & 3.34 & 19.59 & 1.64 \\
\hline $55-64$ Years & 75.71 & 3.61 & 16.55 & 4.14 \\
\hline$\geq 65$ Years & 65.83 & 3.29 & 29.83 & 1.05 \\
\hline \multicolumn{5}{|l|}{ Reading Frequency } \\
\hline Every Day & 75.53 & 2.98 & 14.40 & 7.08 \\
\hline $5-6$ Days/Week & 69.27 & 11.23 & 17.94 & 1.56 \\
\hline $3-4$ Days/Week & 69.82 & 2.29 & 19.52 & 8.37 \\
\hline $1-2$ Days/Week & 68.94 & 5.08 & 19.43 & 6.55 \\
\hline Only Sundays & 72.53 & 5.99 & 20.94 & 0.54 \\
\hline
\end{tabular}

Table 5

Partial Uhilities of each Level of each Atribute in Participant Subgroups Defined by Sex: Age, and Newspaper Reading-Frequency

Brand A Brand B Brand C Brand D With Without With Without $175 \quad 250 \quad 100$

Supplement Supplement Pullout Pullout pesetas Pestas Pesctas

\begin{tabular}{|c|c|c|c|c|c|c|c|c|c|c|c|}
\hline \multicolumn{12}{|l|}{$\operatorname{Sex}$} \\
\hline Total & -0.82 & 1.12 & 1.67 & -1.97 & 0.45 & -0.45 & 0.16 & -0.16 & 0.02 & 0.04 & 0.06 \\
\hline Men & -0.65 & 0.85 & 1.88 & -2.08 & 0.45 & -0.45 & 0.10 & -0.10 & 0.02 & 0.04 & 0.06 \\
\hline Women & -1.13 & 1.61 & 1.30 & -1.79 & 0.44 & -0.44 & 0.27 & -0.27 & 0.02 & 0.04 & 0.06 \\
\hline \multicolumn{12}{|l|}{ Age } \\
\hline $18-24$ Years & -0.49 & 0.52 & 0.76 & -0.79 & 0.47 & 0.47 & 0.47 & -0.47 & -0.06 & -0.13 & 0.0 .19 \\
\hline $25-34$ Years & -1.43 & 1.66 & 1.92 & -2.15 & 0.41 & -0.41 & 0.24 & -0.24 & 0.08 & 0.15 & 0.23 \\
\hline $35-44$ Years & -0.52 & 1.29 & 1.92 & -2.69 & 0.44 & -0.44 & 0.12 & -0.12 & -0.11 & -0.21 & -0.32 \\
\hline $45-54$ Years & -0.23 & 0.61 & 1.89 & -2.28 & 0.54 & $\ldots .54$ & 0.04 & -0.04 & 0.09 & 0.18 & 0.27 \\
\hline $55-64$ Years & -0.84 & 1.07 & 1.82 & -2.06 & 0.42 & -0.42 & 0.11 & -0.11 & 0.09 & 0.18 & 0.27 \\
\hline$\geq 65$ Years & -1.10 & 0.76 & 1.00 & -0.66 & 0.47 & 0.47 & 0.02 & -0.02 & 0.05 & 0.10 & 0.16 \\
\hline \multicolumn{12}{|l|}{ Reading Frequency } \\
\hline Every Day & -0.70 & 0.72 & 2.21 & -2.23 & 0.42 & -0.42 & 0.2[ & $-0.2 \mathrm{I}$ & -0.09 & -0.17 & -0.26 \\
\hline 5 - 6 Days/Weck & -1.10 & 1.21 & 1.33 & -1.44 & 0.35 & -0.35 & 0.03 & -0.03 & 0.22 & 0.45 & 0.67 \\
\hline $3-4$ Days/Week & -0.94 & 1.69 & 0.46 & -1.20 & 0.40 & -0.40 & 0.17 & $\ldots 0.17$ & 0.05 & 0.09 & 0.14 \\
\hline 1 - 2 Days/Week & -0.95 & 1.60 & 1.62 & -2.27 & 0.55 & -0.55 & 0.18 & -0.18 & 0.14 & 0.28 & 0.43 \\
\hline Only Sundays & -0.60 & 1.18 & 1.56 & -2.15 & 0.54 & -0.54 & -0.01 & 0.01 & 0.15 & $0.3 i$ & 0.46 \\
\hline
\end{tabular}


here the partial utility of brand $\mathrm{D}$ was negative (with respect to the other brands); but. of course, this docs not mean that all the money invested so far in the marketing of newspaper $D$ has been wasted. One way of obtaining an assessment of absolute brand equity would be to include a generic product (i.e. a newspaper without a name) in the analysis.

Conjoint analysis can also be used to assess the importanco of brand for different segments of the market (i.e., groups of consumers). To this end, we divided the sample into groups on the basis of a scries of sociodemographic characteristics, including sex, age, and newspaper reading-frequency. Within each characteristic, we then performed separate conjoint analyses, with the results summarized in Tables 4 and 5. Table 4 lists the importance of each attribute in each subgroup.

The attribute brand was the most important in all participant groups. However, a number of betwecn-group differences are apparent. First, brand was more important to men than to women. Second, brand was more imporkant to older $(25$ - 64 years) than to younger ( 18 - 24 years) participants. Third, brand was more important to participants who read a newspaper daily than to participants who only read a newspaper once or twice a week.

Table 5 lists partial utilities (for each participant group) of cach of the levels of each of the four attributes. These data offer detailed information on the "fine tuning" of readers' preferences. For example, the presence of a daily pulhout was rated most highly by younger women, and was less important to older participants.

Considering the levels of the attribute brand, men preferred brand $\mathrm{C}$, and women brand $\mathrm{B}$. When participants werc classified by age, brand $\mathrm{C}$ was preferted in all age groups, although its partial utility with respect to the other newspapers varied considerably. When participants were classified by weekly frequency of newspaper reading, daily readers preferred brand $C$, whereas participants who read newspapers $3-4$ times a week preferred brand $B$; in the remaining groups there was no marked difference in preference for brands $\mathrm{B}$ and $\mathrm{C}$.

\section{Conclusions}

Our results clearly indicate that brand is of major importance in the Spanish national daily market. Brand was the most highly valued attribute in all participant groups, regardless of agc, sex, and frequency of newspaper reading. These results suggest that the managers of newspapers with relatively weak brands (here, $A$ and $D$ ) should not assign significant resources to such extras as pullouts, and should not attempl to compete on price; rather, they should concentrate on creating brand equity.

This central importance of brand is fully in line with previous studies. Park, Iaworski, and MacInnis (1986) have emphasized the importance of strategic management of the concept of image of the brand. involving the detinition of the brand image and its introduction, elaboration, fortification, and control over time, always in accordance with consumer demands.

Studies such as those by Keller (1993), Cobb-Walgren, Ruble, and Donthu (1995), Green \& Krieger (1995), Varcla, Rial, García, Braña, and Olea (1996), and Rial, Varela, Braña, and Lévy (2000) have stressed the importance of building brand value in the light of brand utilities for different consumer subgroups. The underlying assumption of these studies is that the brand will only be of value to the owner of the product if it is already valuable to the consumer: Consequently, it is fundamental to assess the way the value of the brand is created in consumers' minds, and the way this turns into behavior. In this connection, conjoint analysis is of particular value: the utilities estimated in this analysis are a measure of the subjective value that a given product has for a given participant, and also provide information about the attributes on which this value is based (Weber \& Borcherding, 1993).

Our results also provide evidence of the value of conjoint analysis for market segmentation. The importance assigned by participants to cach attribute varied markedly with sex, age, and frequency of newspaper reading. Thus, the ideal product for onc sector of the market may be entirely different from that for another sector of the market. The partial utilities obtained in conjoint analysis can be used as tools for investigating these questions in delail, alone or in conjunction with other techniques such as cluster analysis or discriminant analysis.

In summary, we wish to point out some advantages of using the conjoint analysis method in this context: (a) it offers various possibilities of data collection, making it a simple task for the subjects, as well as highly realistic; (b) from preference data (nonmetric), we obtained motric data that represents the utility or the perceived importance of each level of attribute, or of the total product, which reveals the relative "value" of the different attributes in the competitive market; (c) the information provided by conjoint analysis is capable of predicting the reactions of subjects in the market, as the utilities reliably reproduce their preferences; and (d) this methodology provides results for different consumer groups, and, therefore, is a good tool in market segmentation. Furthermore, as seen in this paper, conjoint analysis can be very useful to solve specific problems in market research and in order to make strategic decisions.

\section{References}

Aaker, D. (1991). Managing brand eqrity: Capitalizing on the walue of brand name. New York: lree Press.

Aaker, D. (1996). Building strong brands. New York: Free Press.

Anderson, N.H. (1974). Infornation integration theory: A brief survey. San Francisco, CA: Freeman. 
Cobb-Walgren, C.J., Ruble, C.A., \& Donthu, N. (1995). Brand equity, brand preference, and purchase intent. Journal of Adventising, 24, 25-40.

Fishbein, M. (1967). A behavioral theory approach to relations between beliefs about an object and the atcitude towards the object. In M. Fishbein (Ed.). Readings in attithde and theorv measurement (pp. 389-399). New York: Wilcy.

Farquhar, P.H. (1989). Managing brand equity. Marketing Resetrsh. 1, 24-33.

Green, P.E., \& Wind, Y. (1975). New ways to measure consumer judgments. Harvard Business Review. 53, 107-117.

Green, P.E, \& Kricger, A.M. (1995). Attribute importance weights modification in assessing is brand's competitive potential. Marketing Science, 14, 253-270

Huber, F. (2000). Conjoint meastement. Methods and applications. New York: Springer-Verlag.

Kapferer, J.N. (1992). Les margues. cupital de lánterprise. Paris: Les Éditions d'Organisation.

Kapferer, J.N., \& Thoneng. J.C. (1991). La margte. Paris: MoGrawHill.

Keller, K.L. (1993). Conceptualizing, measuring. and managing customer-based brand equity. Jounal of Marketing, 57, 1-22.

Kirk, J. (1982). Experimental design: Procedures for the behwioral sciences ( $2^{\text {nd }} \mathrm{cd}$.). Monterrey, CA: Brooks-Cole.

Lancaster, K.I. (1966). A new approach to consumer theory. Jounal of Political Economy, 74, 132-157.

Loudon, D., \& Della Bitta, A.J. (1988). Consumer behavior: Concepts and applications. New York: McGraw-Hill.

Low, G.S., \& Fullerton, R.A. (1994). Brands, brand management and the brand manager system; A critical-historical evaluation. Joumal of Marketing Research, 31, 271-288.
Norusis, M.J. (1994). SPSS. Professiona! Statistics 6. [. Chicago: SPSS.

Park, C.W., Jaworski, B.J., \& Maclnnis, D.J. (1986). Stratogic brand concept-image management. Joumal of Marketing, 50 . 135-145.

Park. C.W. \& Srinivasan, V. (1994). A survey-based method for measuring and understanding brand equity and its extendibility Jounal of Marketing Researd, 31,271-288.

Rial, A., Varela. J.. Braña. T.. \& Levy, J.P. (2000). El valor de la marca a partir de su relación con el consumidor. Psicothema, 12. $247-254$.

Rosenberg, M.J. (1956). Cognitive structure and attiludinal affect. Journal of Abnomat and Social Psychology, 53, 367-372.

Shocker: A.D.. Srivastava, V.. \& Ruckert, R.W. (1994). Challenges and opportunitics ficing brand management: An introduction to the special issue. Jounal of Marketing Research, 76, 149-158.

Varcla. J., \& Braña, T. (1996). Análisis conjunto aplicado a la investigacion comercial. Madrid: Pirámide.

Varela, J., Rial, A., Garcit. C., Braña, T. \& Olea. J. (1996). Una medicla de la implicaciōn de los consumidores con las marcas comerciales. Psicothema, \&, 3, 543-551.

Weber, M., \& Borcherding. K. (1993). Behavioral influences on weight judgments in multi-attribute decision making. European Joumal of Operational Researth, 67, 1-12.

Wilkic, W.L. \& Pessemier, E.A. (1973). Issues in marketing's use of multi-atuibute models. Journal of Markating Research, 10 . 428-441.

Received September 13, 1999

Revision received June 19, 2000

Accepted September 11, 2000 